\author{
Evheniia POSTYKINA, \\ orcid.org/0000-0003-2675-0224 \\ Lecturer at the English Language Department \\ Petro Mohila Black Sea State University \\ (Mykolayv,Ukraine)postykina@yahoo.com
}

\title{
COMPRESSION IN ENGLISH UKRAINIAN (RUSSIAN) AND UKRAINIAN (RUSSIAN) ENGLISH TRANSLATION OF GEODETIC TERMINOLOGY
}

The article considers speech compression as one of the key strategies of simultaneous translation on the materials of assignments of students-geodesists.

The analysis of the strategy allowed to identify the levels of language at which this technique is actively used, as well as to identify techniques for creating a compression.

It is proposed to consider compression not as a structural element, but as a way to solve semantic problems.

The ability to find equivalents to geodetic terminology becomes necessary because it helps save time.

One of the key strategies of the studied type of translation is speech compression, i.e., the compression of the speaker's speech, which inevitably occurs in simultaneous translation. This phenomenon often occurs during the translation of texts and terminology in the classes of students of surveying. Often, comprehensive research on this problem is not conducted, and in the learning process there is no emphasis on training this extremely important skill. Therefore, the problem still remains relevant and requires more detailed study. The student-surveyor, translating consistently, is constantly faced with the same task: to convey the content of the heard phrase as fully and accurately as possible. And no matter how high a level of training his RAM is, he can't do without memory alone. It is necessary to understand the meaning of what has been said, that is, to logically classify speech in the course of the case. Some translation methodologists recommend isolating so-called semantic peaks in the heard phrase. Experience with the application of the technique of semantic peaks, however, has shown that the quality of translation of each individual phrase in the classroom increases, but the speed of translation falls sharply, which is a significant disadvantage in the practice of translation. The reason for the slowdown, apparently, is that, in addition to the current ones, the translator is forced to solve another logical problem. Therefore, it is necessary to count on auxiliary receptions which will not lead to deceleration of pace. And these can be only such methods which the student applies without distraction, automatically. We developed the development of the automatic skill of isolating the main thing in the sentence as the basis of exercises under the conditional name "syntactic deployment".

Key words: speech compression; simultaneous compression; simultaneous translation.

Евгенія ПОСТИКІНА, orcid.org/0000-0003-2675-0224 викладач кафедри англійської мови

Чорноморського національного університету імені Петра Могили (Миколаїв, Украӥна) postykina@yahoo.com

\section{КОМПРЕСІЯ В АНГЛО-УКРАЇНСЬКОМУ (РОСІЙСЬКОМУ) ТА УКРАЇНСЬКО (РОСІЙСЬКО)-АНГЛІЙСЬКОМУ ПЕРЕКЛАДІ ГЕОДЕЗИЧНИХ ТЕРМІНІВ}

\footnotetext{
У статті розглядається стиснення мовлення як одна із ключових стратегій синхронного перекладу на матеріалах доручень студентів-геодезистів.

Аналіз стратегії дав змогу виявити рівні мови, на яких ия техніка активно використовується, а також визначити техніки створення ефекту стиснення.

Компресію пропонується розглядати не як структурний елемент, а як спосіб вирішення семантичних завдань.

Вміння знаходити відповідники до геодезичної термінології стає необхідним, оскільки допомагає економити час.

Однією із ключових стратегій досліджуваного типу перекладу є стиснення мови, тобто стиснення мови мовия, щя неминуче відбувається при синхронному перекладі. Це явище часто виникає під час перекладу текстів та термінології на заняттях студентів-геодезистів. Часто всебічне дослідження цієї проблеми не проводиться, i в процесі навчання не робиться акцент на навчанні иій надзвичайно важливої навички. Тому проблема все щче залишається актуальною і вимагає більш детального вивчення. Студент-геодезист, послідовно перекладаючи, постійно стикається з одним і тим же завданням: якомога повніше і точніше передати зміст почутої фрази.
} 
І яким би високим не був рівень підготовки його оперативної пам'яті, він не може обійтися без самої пам'яті. Необхідно зрозуміти зміст сказаного, тобто логічно класифікувати мовлення у проиесі справи. Деякі методисти перекладу рекомендують виділяти так звані семантичні піки у почутій фразі. Однак досвід застосування техніки семантичних піків показав, щчо якість перекладу кожної окремої фрази в класі підвищується, але швидкість перекладу різко падає, щуо є суттєвим недоліком у практиці перекладу. Причина уповільнення, мабуть, полягає в тому, що, крім нинішніх, перекладач змушений вирішити ще одну логічну проблему. Тому слід розраховувати на допоміжні прийоми, які не призведуть до уповільнення темпу. І ие можуть бути лише такі методи, які студент під час перекладу застосовує без відволікання, автоматично. Ми розробили розвиток автоматичного вміння виділяти головне у реченні як основу вправ під умовною назвою «синтаксичне розгортання».

Ключові слова: стиснення мови; одночасне стиснення; синхронний переклад.

Formulation of the problem. Compression of the text, is mostly achieved by omitting redundant elements of expression, elements that are reproduced from the context or extra-linguistic situation, as well as by using more compact constructions. VI Karaban understands compression as "any reduction in the number of sentence elements or removal of sentence elements in translation" (Зубанова, И.В., 270), emphasizing that the main reasons for compression may be the grammatical structure of the translation language, but it does not exclude stylistic and pragmatic factors as well. I will agree with those scholars who believe that compression should be understood primarily as a grammatical phenomenon, as a reduction in volume and simplification of the structure of a sentence (text) in translation, through the use of more concise grammatical forms. Thus, this study is an attempt to analyze and determine the specifics of the use of compression in the translation from Ukrainian into English, identifying the appropriate grammatical forms and constructions, differences between which in the compared languages lead to text collapse in the translation process.

Research analysis. Determining compression, its specifics and features of application in the translation process is not the subject of frequent and thorough research in translation studies and linguistics. Only a number of researchers address this issue in their works, among them we will name VI Carabana, L.L. Нелюбина, T.A. Казакову, O.B. Breus, Y.I. Kaminsky, VV Myroshnichenko and others. The dictionary definition of the term "compression" is as follows: "saving language means to express the same content" (Покрашенко Наталья, 85). When determining compression, we talk about compression in the process of simultaneous translation, speech compression, text compression, which, in turn, is defined as: "transformation of the source text in order to give it a more concise form" (Покрашенко Наталья, 85).

Purpose of the article. Everyone knows the main task of translation is to convey information as completely and accurately as possible. When solving this problem, there are often difficulties due to a number of reasons. The main one is the different types, which include English and Russian. The first is analytical language, and the second is synthetic. The English language is characterized by a desire to save grammar. In other words, English sentences are characterized by compression. What is clear to a native English speaker in the Ukrainian version requires an addition, thanks to which it is possible to avoid violations of the norms of the Ukrainian language and achieve adequate translation.

The main material. The study of language compression in domestic linguistics has so far been presented mainly by studies devoted to simultaneous translation from English into Ukrainian. In this case, the need for compression is most obvious, as it is due to the excess of the average component of the word length in the Ukrainian language over the average word length in the English language.

The purpose of the work is to identify the main factors influencing the mechanism of implementation of the strategy of speech compression in translation, as well as to determine the main techniques used by the translator under the influence of these factors.

During the study the following tasks were solved:

- analysis of the identified cases of speech compression in terms of methods of implementing the mechanism of speech compression;

- analysis of methods of realization of the mechanism of speech compression from the point of view of the factors underlying them;

- classification of methods of implementation of speech compression in relation to the factors underlying them;

The object of research is the translation of a literary text from Ukrainian into English. The subject of research - methods of language compression in the process of translation from Ukrainian into English.

The theoretical significance of the work is to supplement the list of methods for implementing the strategy of language compression, as well as to compile, for the Ukrainian-English language combination of translation, classification of methods of language compression based on the factors underlying the implementation of compression. The practical significance of the course work lies in the possibility 
of using its results to optimize the practice of literary translation. In addition, the results of this study can be used in the process of training translators.

For the term of compression, we have no unambiguous interpretation. Most often compression is the process of generating economical syntactic constructions, which achieves the ability to express a certain amount of information with minimal language (Gurin, Belyaeva, 2007, p. 150). In linguistics, there are two interpretations of compression: in the "broad" and "narrow" sense. Compression in a broad sense is understood as one of the main trends in the functioning of language, which operates in all areas of this functioning, which manifests itself in different ways. Therefore, it is possible to speak of compression in the "narrow" sense as a set of tools that serve the purposes of its implementation in a broad sense at all language levels.

The term "compression" is often found in research and translation studies, which states that, in general, compression is characteristic of the translation from Russian into a foreign language, and not vice versa. Characteristic features of the scientific style are its informativeness (content), logic (strict sequence, clear connection between the main idea and details), accuracy, objectivity and clarity. Terms give an accurate indication of real objects and phenomena, provide a clear understanding of information.

It is important to note that to achieve the same goal allows a certain variability of funds in quantitative terms. According to the point of view available in physiology, the mental area and the area of movements are the sphere in which the principle of economy finds its expression in human activity. Thus, the desire of man to master such movements, which would be associated with the lowest expenditure of human energy, without affecting the results of achieving the ultimate goal, is natural.

In modern linguistic literature, the desire for economic expression of a certain meaning is called the term compression, probably borrowed from the theory of communication. However, each researcher understands this meaning differently: the ability of one morpheme to "combine" within a word several categorical meanings, simplicity of syntactic connections (3), the concomitant phenomenon of syntactic expansion (4), the process of generating economical syntactic constructions (5). Thus, we can assume that the principle of economy applies both in the language system and in language activities.

Since the ways of saving are different, it is necessary to distinguish between saving in language and saving in language. In speech activity, it can be carried out through an ellipse, when part of the utterance is omitted as redundant; replacement, when part of the sentence turns into a phrase; syntactic reduction. (6) Ellipse, replacement, reduction is not natural, as they are due to the context or certain extralinguistic situations, which, of course, is a feature of these phenomena.

Representing detailed syntactic units, elliptical or abbreviated constructions remain socially understandable, but also commonly used due to the fact that the language chain as a carrier of information is able to transmit and transmit the necessary unambiguous information within a certain area of communication. As a rule, for Ellipse it is a colloquial language, where sentences function within the limits of linguistic integrity. Syntactic reduction is more often used in a specialized functional style, in particular, it is the language of newspaper headlines and telegrams, where the reduction is subjected to units that do not carry essential information in terms of communication.

As for compression, it is a special kind of transformation. It is based on the internal properties of the language system and helps to reduce the expanded syntactic constructions to a less complex form, transmitting the same amount of information as the full expanded syntactic units. V. Matezius, one of the founders of the Prague Functional School, used the term "complex condensation" instead of the term "compression".

However, in domestic linguistics, the term "complex condensation" is not used, possibly because it refers to the compression of the structure of only the adjunct sentence. While the term "compression" is used in a wider range, and they denote all the natural ways of implementing the principle of economy in language. Given that the brevity of the expression presents significant difficulties in translating, for example, from English to Russian, this article attempts to systematize some of the most typical ways of decompressing compressed syntactic units.

Immediacy of word formation in English is a common way to create compression at the morphological level. Significant compression is achieved through the use of verb forms, namely the infinitive, the communion and the gerund, which in turn creates the problem of finding the appropriate equivalents in translation. Summarizing the above, we can conclude that compression in language is manifested at all levels of the language system and is a highly productive means of language economy. When translating compressed syntactic units, it is sometimes necessary to resort to the deployment, replacement or input of other parts of speech.

V.M. Ilyukhin (2001), following G.V. Chernov, offers a fairly compact classification, distinguish- 
ing only four types of compression by the method of its implementation: 1) syllabic (choice of a shorter word); 2) syntactic (choice of a shorter construction); 3) lexical (expression of thought in fewer words) and 4) semantic (reduction of repetition of redundant words).

Some other authors who have written on this topic, on the contrary, offer long lists of compression techniques, in which you can find very diverse things. Thus, I.V. Gurin (2009) provides the following list:

- replacement of the full name with an abbreviation or abbreviation name,

- omission of a homogeneous member,

- elimination of repetitive syntactic components,

- omission of deviation from the topic,

- omission of the appeal,

- omission of redundant semantic elements, supplemented by the extralinguistic situation of communication,

- omission of redundant semantic elements, supplemented by background knowledge of the participants of the communicative act,

- omission of precise information,

- omission of the politeness formula,

- lowering of the introductory structure,

- lowering of the plug-in design,

- DE substantiation,

- compression of the predicative-object structure into a verb,

- replacement of the predicative construction with a verb with a prefix,

- omission of a definite construction or adverb,

- substitution / contraction of a phrase,

- elimination of differential semantic components with the transition from the species concept to the generic,

- omission of redundant semantic elements, supplemented by the context of communication; as well as

- concretization due to the previous context,

- parallelism compression,

- omission / replacement of a word that requires a detailed explanation,

- transformation of a verb into a predicative structure "to be + adjective / participle / preposition",

- generalization (collapse of a syntagm to a word with a common meaning),

- omission of the emphases,

- unmotivated omission of a sentence or part thereof,

- replacement of a full verb with a verb of broad semantics,

- transformation of a simple sentence into an introductory-existential one construction,
- adverbialization,

- compression of the allied structure.

As we see, there are techniques of morphological, lexical, syntactic, pragmatic nature, as well as just omissions, i.e., decisions to skip some information, leaving it untranslated. Among other things, this list itself provokes a desire to compress it due to the repetition and redundancy of many elements: for example, "parallelism compression" can be considered an option to "eliminate repetitive syntactic components", and "collapse the phrase to a word with common meaning" is private case of "substitution / contraction of a phrase".

For example, we can see how students translate different geodesic terminology. Let's consider it on the basis of L.M. Nikulina Book "COLLECTION OF GENERAL SCIENTIFIC AND TECHNICAL TEXTS IN ENGLISH" for undergraduates, students of the 1st, 2nd courses. Part 2 (Fig. 1).

In this case, the compression is performed by moving from the species concept to the genus. From the context it becomes clear that such statistics are available to the Ministry of Economy, and the translator does not have to say the full name of the state structure. It helped not to listen to the rhyme and to reproduce the precise information correctly.

Some researchers additionally highlight the syllabic level, i.e., the conscious choice of a shorter word (Poluyan 2011: 10). But if in the above cases there is a deliberate choice of strategy, then in the case of syllabic compression it is impossible to determine whether the translator used a word because it was shorter than the analogue suggested by the researcher, or because it was the only word at the time of translation it occurred to him.

It is also worth noting that the above tactics of syntactic, semantic, lexical compression can be trained and eventually begin to use not only consciously but also unconsciously, developing a certain style of translation. In the case of syllabic compression, training is possible only by increasing the active vocabulary, the study of synonymous series. But in the end, it turns out that, even knowing these synonyms, a person due to cognitive features will have to spend seconds to analyze and choose a shorter word.

Student can formally consider a way of performing compression, but we do not turn to it in our study.

He should understand that the methods of compression must be applied depending on the function of the segment in the semantic structure of the statement and the novelty, the value of the information contained in it.

For example, it is recommended to resort to compression in the subject of the message to be ready to 


\section{Text 38}

\section{FROM THE HISTORY OF ECONOMICS}

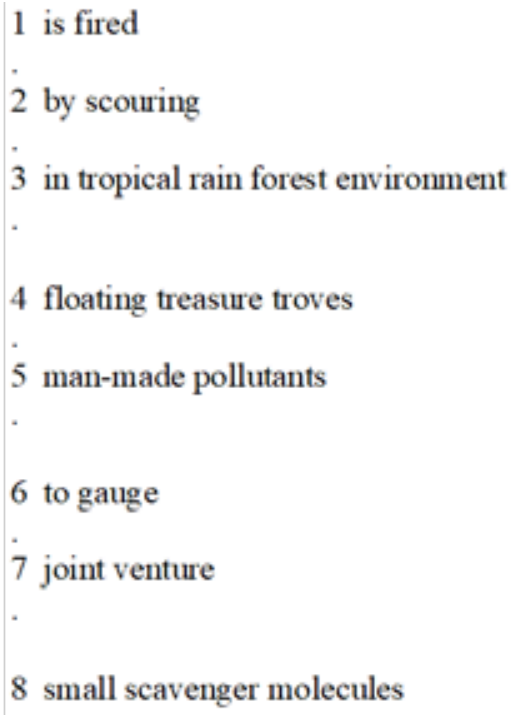

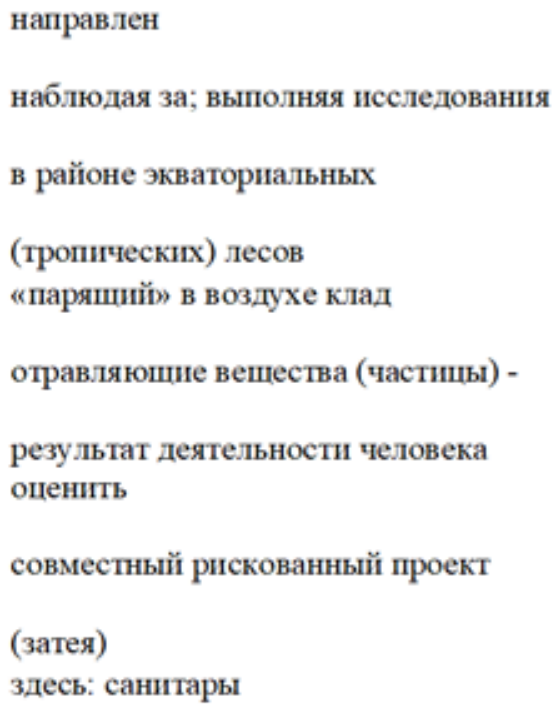

\section{Text 30}

\section{THE ROYAL OBSERVATORY AT GREENWICH}

1. against the background of the stars

2. upon the highest ground

3. by-products

4. time zone system

5. through the centre of the

Transit Instrument

6. a fit place

7. Herstmonceux in Sussex

\author{
на фоне звезд \\ здесь: на самом высоком холме \\ здесь: дополнительные функции \\ служба времени \\ через ось вращения пассажного \\ инструмента \\ (универсальный прибор для \\ определения астрономической \\ долготы и широты) подходящее \\ место \\ Хортмонсо (графство Сасекс)
}

Fig. 1

listen and speak a rhyme (precise information, terms, the main semantic segment). This will greatly facilitate the task of the translator and will reduce the lag from the speaker, to avoid crumpled translation. It is this skill that should be considered when teaching students simultaneous translation.

Conlusions. Thus, it turns out that compression is one of the ways to solve not so much structural as semantic, that is, communicative and functional, problems during translation (Zubanova 2017: 44). And the translator is a communication specialist. In the process, he skillfully chooses tactics to reduce background information and preserve the core, the meaning of the statement.

In this case, the translator always evaluates in which case the compression strategy is acceptable and effective, and in which case it is unacceptable or undesirable.

\section{BIBLIOGRAPHY}

1. Афанасьева, М.С. Употребление приемов речевой компрессии при синхронном переводе. Международный научный журнал «Символ науки». № 3. 2016. С. 111-114.

2. Завьялова, В.Л. Фонетические аспекты устного опосредованного перевода. Казанский педагогический журнал. № 6. 2015. С. 35-47.

3. Зубанова, И.В. Просто убавь воды. О компрессии в синхронном переводе. № 2. 2017. С. 43-53.

4. Покрашенко Наталья. Языковая компрессия в Твиттер-коммуникации. Омск, 2018. С. 87-96. 
5. Полуян, Иван. Компрессия в синхронном переводе с английского языка на русский и с русского на английский. Валент, 2011. 112 c.

6. Хромых А.А. «Конференц-перевод (попытка осмысления теоретических основ)». Языкознание $и$ литературоведение. vol. 1. № 9. Лютий 2017. С. 193-196.

7. Парахина Азалия. Пособие по переводу технических текстов с английского языка на русский. Высшая школа, 1982. C. 190-192.

8. Черная Анна. Английские общенаучные тексты. Наука, 1982. С. 165-170.

9. Павлова Зинаида и Юлия Тупикова. Сборник общенаучных текстов на английском языке. Высшая школа, 1974. C. $112-115$.

\section{REFERENCES}

1. Afanas'yeva M.S. Upotrebleniye priyemov rechevoy kompressii pri sinkhronnom perevode [The use of speech compression techniques for simultaneous translation] International scientific journal "Symbol of Science” № 3. 2016. pp. 111-114. [in Russian]

2. Zav'yalova V.L. Foneticheskiye aspekty ustnogo oposredovannogo perevoda [Phonetic aspects of mediated interpretation] Kazan pedagogical journal. No. 6. 2015. pp. 35-47. [in Russian]

3. Zubanova I.V. Prosto ubav' vody. O kompressii v sinkhronnom perevode [Just turn down the water. On compression in simultaneous translation] Bridges. Journal of translators. 2017. No. 2 (54). pp. 43-53. [in Russian]

4. Pokrashenko N.A. YAzykovaya kompressiya v Tvitter-kommunikatsii [Language compression in Twitter communications] Digest2017: collection of articles. Art. based on materials of graduate qualification works of students of the Faculty of Foreign Languages. Omsk, 2018, pp. 87-96. [in Russian]

5. Poluyan I.V. Kompressiya v sinkhronnom perevode s angliyskogo yazyka na russkiy i s russkogo na angliyskiy [Compression with simultaneous translation from English into Russian and from Russian into English]. Valent, 2011.112 p. [in Russian]

6. Khromykh A.A. Konferents-perevod (popytka osmysleniya teoreticheskikh osnov) [Conference translation (an attempt to comprehend the theoretical foundations)] Philological sciences. Questions of theory and practice. No. 9 (74): in 2 hours, part 1. 2017. p. 193-196. [in Russian]

7. A.V. Prakhina. Posobiye po perevodu tekhnicheskikh tekstov s angliyskogo yazyka na russkiy. [A guide for translating technical texts from English into Russian.] "High school”, 1982. 190-192 pp [in Russian]

8. A.I. Chernaya. Angliyskiye obshchenauchnyye teksty.[ English general scientific texts.] "Science”, 1982. 165-170 pp. [in Russian]

9. Z.S. Pavlova, YU.Ye. Tupikova. Sbornik obshchenauchnykh tekstov na angliyskom yazyke.[ Tupikova. Collection of general scientific texts in English.] "High school", 1974. 112-115 pp. [in Russian] 